\title{
ELEMENTAL CHARACTERIZATION OF HUMAN BLOOD USING LASER-INDUCED BREAKDOWN SPECTROSCOPY UTILIZING 355 NM Nd: YAG OPERATED AT REDUCED PRESSURE OF He GAS
}

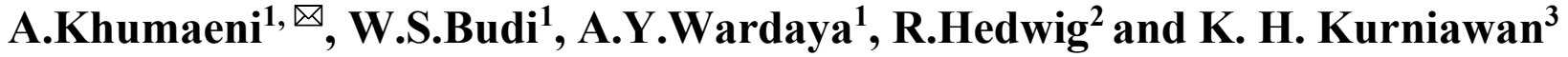 \\ ${ }^{1}$ Department of Physics, Faculty of Science and Mathematics, Diponegoro University, \\ J1. Prof. Soedharto, S.H., Tembalang 50275, Semarang, Indonesia \\ ${ }^{2}$ Bina Nusantara University, Jakarta Barat 11480, Indonesia \\ ${ }^{3}$ Maju Makmur Mandiri Research Center, Kembangan, Jakarta Barat, Indonesia \\ ${ }^{\square}$ Corresponding Author: khumaeni@fisika.fsm.undip.ac.id
}

\begin{abstract}
The human blood serum has often been used as a medium for diagnoses of various diseases based on elemental composition. In this paper, elemental identification and analysis of human blood serum have been performed using a standard LIBS technique utilizing $355 \mathrm{~nm} \mathrm{Nd}$ : YAG laser under He surrounding gas. Experimentally, human serum was homogeneously dropped on a copper metal plate to produce a thin film. The film was then evacuated in a sample chamber, which is filled with He gas at 5-3 torr. A Nd:YAG laser was bombarded on a film to produce a breakdown plasma. Some elements in the serum from the normal and tuberculosis (TB) patients have successfully been identified, including $\mathrm{C}, \mathrm{H}, \mathrm{O}, \mathrm{Ca}$, and $\mathrm{Na}$. The analyte intensities from the human serum of TB patients have good stability with laser shot dependence in different positions. A preliminary test to distinguish the TB patient from normal patient was made based on $\mathrm{Ca}$ elements in the blood serum. Namely, the $\mathrm{Ca}$ intensities from TB patient is much higher than the case of a normal patient.

Keywords: Human Blood Serum, TB Patient, LIBS, Laser-induced Plasma Spectroscopy, 355 nm Nd:YAG Laser RASĀYAN J. Chem., Vol. 14, No.4, 2021
\end{abstract}

\section{INTRODUCTION}

Elements deposited in the human blood serum have attracted many researchers, especially in the field of medical researches. ${ }^{1}$ The human serum contains essential elements, which are very important for human life. Some imperative elements are nitrogen, oxygen, hydrogen, carbon, potassium, phosphorus, chlorine, and magnesium, while the essential trace elements are calcium, iron, zinc, manganese, chromium, iodine, silicon, and arsenic. These elements should be present in the human blood in a fair constant concentration. Nutritional elemental deficiency or abundance in the human body, including human blood serum, leads to susceptibility to infectious diseases. The human serum has often been often used as media for diagnoses of various diseases based on elemental composition. ${ }^{2}$ Therefore, sensitive and accurate elemental identification and analysis of blood serum are indispensable.

Some imaging and spectroscopic methods have been commercially purchasable and employed in the study of disease diagnosis based on elemental composition. These ICP-OES and NAA spectroscopy. Such methods are widely adopted for accurate and sensitive elemental analyses. However, tedious sample pretreatments are needed and the techniques suffer from serious spectra interference because of multielements present in the sample target. ${ }^{3-5}$

Laser-induced breakdown spectroscopy (LIBS) is a rising-star technique for elemental analysis in many kinds of samples such as gases, liquids, and solids. ${ }^{6-10}$ Experimentally, a pulse Nd:YAG laser $1064 \mathrm{~nm}$ is used to induce a breakdown plasma, which plays a role as an excitation source of atoms from the material target. The applications of LIBS to elemental analysis of human blood serum have been reported in some literature. However, it is known that LIBS has a limitation for the analysis of liquid samples such as blood 
serum, due to the low sensitivity and delicate sample preparations. Furthermore, a standard LIBS technique operated at atmospheric ambient air is very delicate to detect $\mathrm{H}$ and $\mathrm{C}$, which are the main elements in the blood serum, because of the time mismatch effect. ${ }^{11-12}$

In this work, we proposed laser-induced plasma spectroscopy using $355 \mathrm{~nm} \mathrm{Nd:YAG} \mathrm{laser} \mathrm{in} \mathrm{reduced}$ pressure of $\mathrm{He}$ gas for identification and analysis of elements in the blood serum, including human blood serum from the normal patient and tuberculosis patients. The use of He gas in the study is to produce lots of He metastable atoms (He* atoms) in the plasma. The He* atoms work, assisting a process of atomic excitation of the analyte atoms, including light atoms of carbon and hydrogen. The sample was made as a film deposited on a copper metal subtarget. The result certified that the element intensities of $\mathrm{C}$ and $\mathrm{H}$ in both human blood serum of normal and TB patients are successfully enhanced with optimum $\mathrm{S} / \mathrm{N}$ ratio and without any broaden line. Furthermore, the human blood serum of the TB patients can be distinguished from the blood serum of normal patients based on trace elements of $\mathrm{Ca}$ identified in the spectrum.

\section{EXPERIMENTAL}

Figure-1 displays a setup used in this paper. First, an Nd:YAG laser $(355 \mathrm{~nm}, 10 \mathrm{~Hz}$, energy of $70 \mathrm{~mJ})$ was irradiated and focused on a sample target using a quartz lens ( $\mathrm{f}=150 \mathrm{~mm}$ ) to initiate and produce a breakdown plasma. Experimentally, the sample target was put in a chamber, in which the helium gas (airliquid, purity of $6 \mathrm{~N}$ ) was used as an environmental gas of sample with a flowing rate of 10 liters per minute and gas pressure of 5 torr.

The human blood serum collected from the normal patients and TB patients at Diponegoro National Hospital was used as a sample target. For the experiment, $1 \mathrm{ml}$ liquid serum was poured on a copper metal plate ( $99.9 \%$ purity) with a dimension of $0.1 \times 20 \times 20 \mathrm{~mm}^{3}$. The serum was homogeneously spread on the surface of $\mathrm{Cu}$ plate. The serum was then placed at room temperature for 30 minutes to produce a serum film. During data acquisition, the sample was put in a chamber and was rotated with a rotation rate of 2 rotations per minute $(\mathrm{rpm})$.

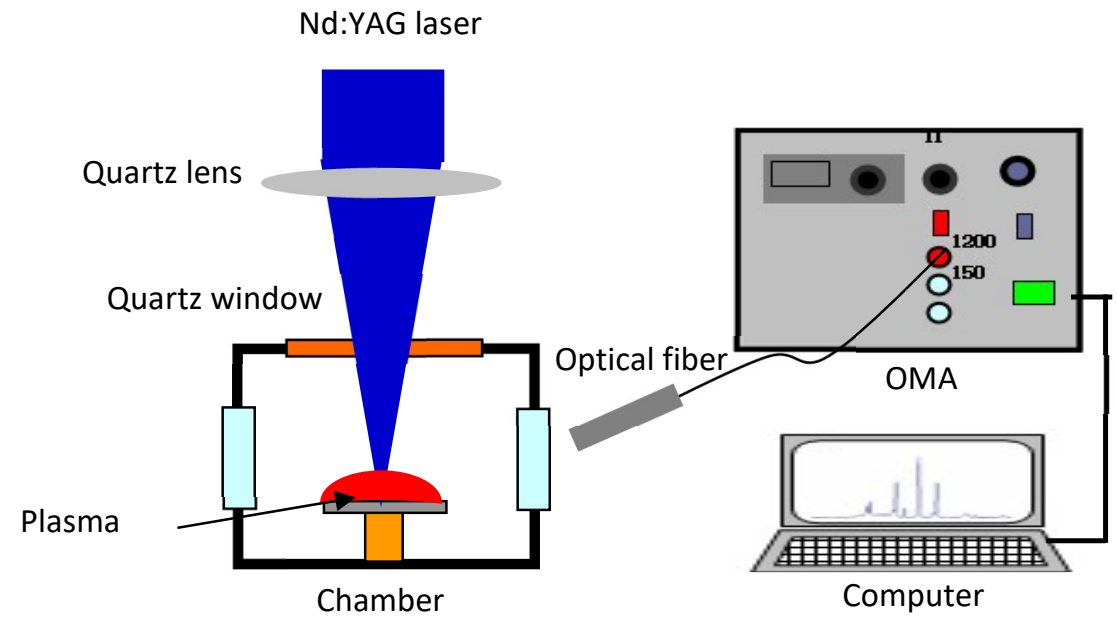

Fig.-1: Experimental Setup used in this Work

The atomic emission spectrum was obtained from the breakdown plasma by using an Echelle spectrograph (Mechelle M5000, Andor) via an optical fiber that is connected to the spectrograph. The delay time and gate widths are $1 \mu \mathrm{s}$ and $5 \mu \mathrm{s}$, respectively.

\section{RESULTS AND DISCUSSION}

Initially, spectrochemical characteristics of $\mathrm{Cu}$ metal plate as a metal sub-target during the study were examined. Figure-2 displays the analytical spectrum of $\mathrm{Cu}$ taken from the $\mathrm{Cu}$ metal plate only. Typical resonance lines of neutral $\mathrm{Cu}$ occur at $324.7 \mathrm{~nm}$ and $327.4 \mathrm{~nm}$. The other lines of typical neutral $\mathrm{Cu}$ are also detected at $510.5 \mathrm{~nm}, 515.3 \mathrm{~nm}$, and $521.8 \mathrm{~nm}$. These lines are contributed from the $\mathrm{Cu}$ plate used as a subtarget. No other elements are identified from the $\mathrm{Cu}$ sub-target. 
RASĀYAN J. Chem.

Vol. 14 | No. 4 |2413-2419| October- December | 2021

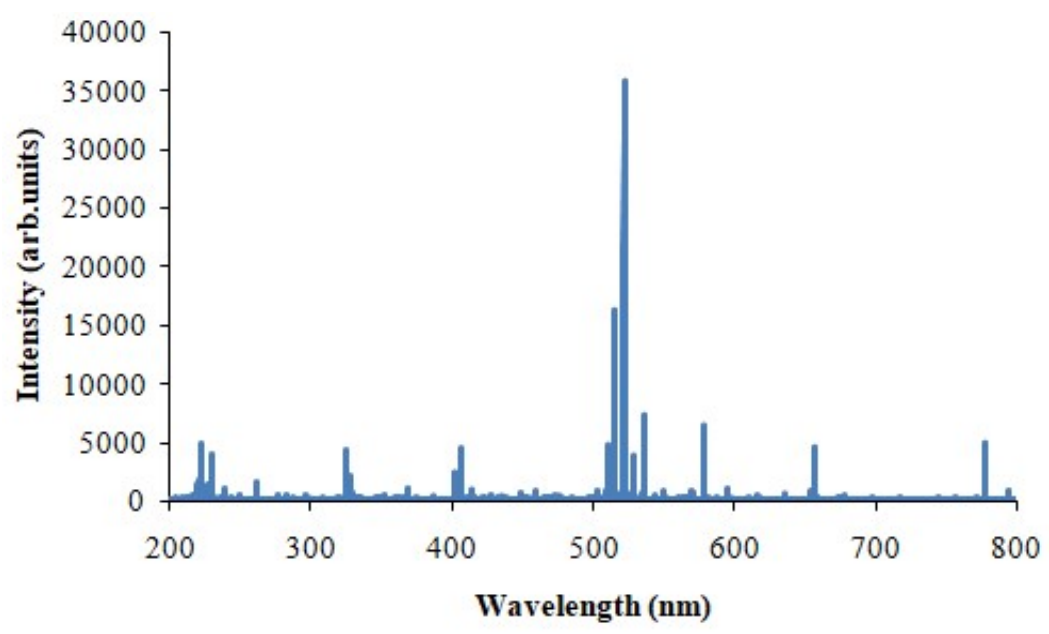

Fig.-2: An Analytical Spectrum is taken from the $\mathrm{Cu}$ Metal

Further work was the identification of elements from the human blood serum. Figure-3 displays an emission spectrum of the human blood serum of normal patients using the present LIBS technique. The laser energy used was $70 \mathrm{~mJ}$. The analytical lines of neutral $\mathrm{C}, \mathrm{H}$, and $\mathrm{O}$ occur clearly at $247.8 \mathrm{~nm}, 656.3 \mathrm{~nm}$, and 777.7 $\mathrm{nm}$, respectively. The other lines of neutral sodium at $588.9 \mathrm{~nm}$ and $589.5 \mathrm{~nm}$, ionic $\mathrm{Ca}$ at $393.3 \mathrm{~nm}$ and $396.8 \mathrm{~nm}$ appear faintly in the spectrum. Those elements are major and minor elements in the human blood serum, as reported here. ${ }^{13}$ In addition, typical lines of neutral Cu clearly occur at $324.7 \mathrm{~nm}, 327 \mathrm{~nm}, 510.5$ $\mathrm{nm}, 515.3 \mathrm{~nm}$, and $521.8 \mathrm{~nm}$. These lines are contributed from the $\mathrm{Cu}$ plate used as a sub-target.

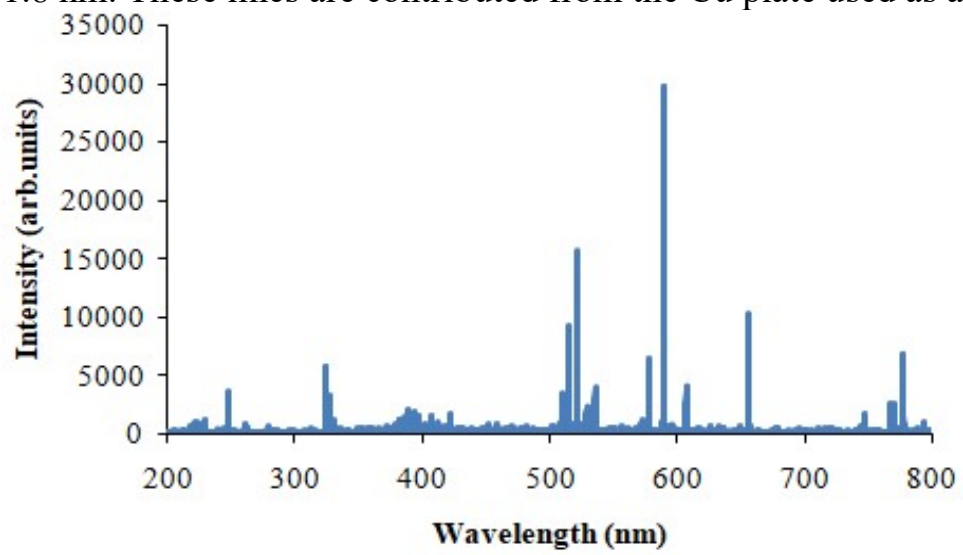

Fig.-3: The emission spectrum is taken from the human blood serum of a normal patient at a reduced pressure of ambient air

To obtain optimum intensity and $\mathrm{S} / \mathrm{N}$ ratio of the analyte, the effect of laser energy on emission intensities of major and trace elements in normal human blood serum was examined. Figure-4 shows the laser energy dependence to emission intensities of $\mathrm{C}, \mathrm{H}$, and $\mathrm{O}$ at $247.8 \mathrm{~nm}, 656.3 \mathrm{~nm}$, and O I $777.7 \mathrm{~nm}$, respectively, and $\mathrm{Ca}$ I $393.3 \mathrm{~nm}$. It can clearly be seen that the $\mathrm{S} / \mathrm{N}$ ratio of all elements increases with increasing the laser energy from 30 to $70 \mathrm{~mJ}$. As reported in the paper, ${ }^{14}$ atomic excitation in the plasma region effectively happens with an increment of laser energy. However, it should be mentioned that the intensities of atoms remained stable when the laser energy was much more increased, which might be due to saturation. Also, when laser energy was more increased, the ablation of the $\mathrm{Cu}$ sub-target metal increased, increasing the ablated $\mathrm{Cu}$ intensities and thus disturbing the emission lines of analytes. Therefore, in this present work, the laser energy of $70 \mathrm{~mJ}$ was selected during the experiment for obtaining the optimum emission intensities and $\mathrm{S} / \mathrm{N}$ ratio of analytical lines.

The effect of ambient He gas in the intensity enhancement was also studied. The use of He as a surrounding gas can produce He metastable atoms, which play a role in the excitation process. ${ }^{15-16}$ Figure-5 displays the human blood spectrum of a normal patient. It appears that the total emission intensities of analytical lines 
in He gas increased almost 4 times compared to the case of ambient air (Fig.-3). All major and trace elements, including neutral $\mathrm{C}$ at $247.8 \mathrm{~nm}$, ionic $\mathrm{C}$ at $393.3 \mathrm{~nm}$ and $396.8 \mathrm{~nm}, \mathrm{H} \mathrm{I} 656.3 \mathrm{~nm}$, He I 667.8 $\mathrm{nm}$, neutral $\mathrm{Na}$ at $588.9 \mathrm{~nm}$ and $589.5 \mathrm{~nm}$, and O I $777.7 \mathrm{~nm}$ are clearly identified with increasing the intensities compared to the case in ambient air.

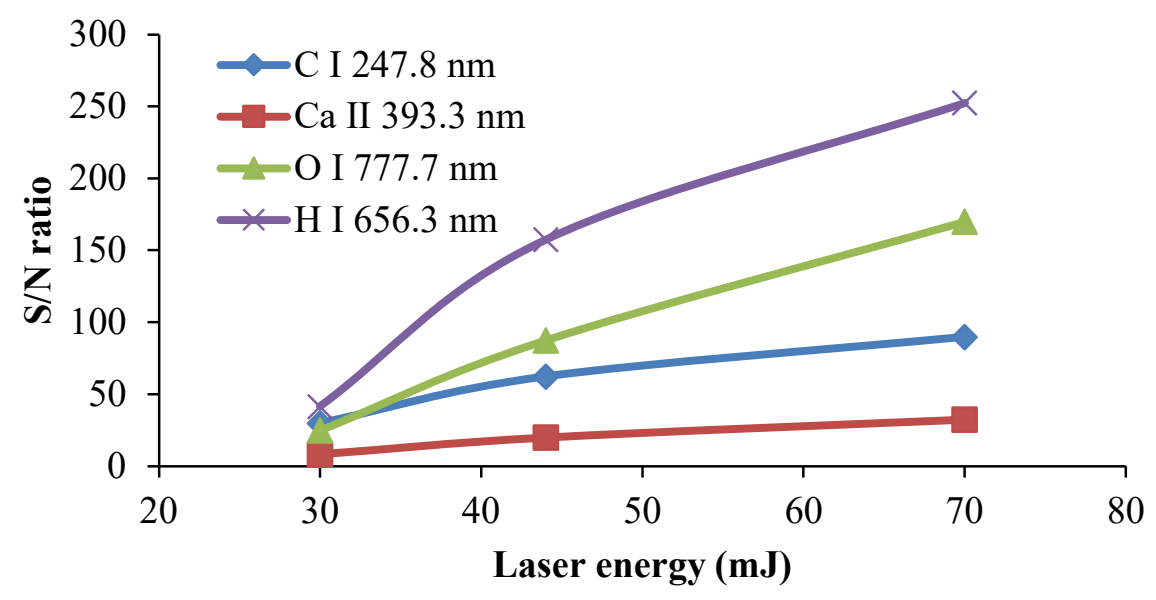

Fig.-4: Laser energy dependence of the emission intensities of analyte taken from the human blood serum of the normal patient

It is assumed that the increment of the total emission intensities happens in the He plasma due to the different excitation processes. Namely, the excitation process in the He plasma region takes place through He metastable atoms (He* atoms). ${ }^{17-18}$ In this process, lots of He metastable atoms, which have a very high potential energy of $19.8 \mathrm{eV}$, produce in the plasma region. $\mathrm{He}^{*}$ atoms collide with analyte atoms and by transferring the potential energy of $\mathrm{He}^{*}$ atoms, the analyte atoms are excited and ionized via the penning effect. The ionized analyzed atoms are then recombined to produce atomic emissions. All the process follows the question below,

$$
\begin{aligned}
& \mathrm{He}^{*}+\mathrm{X} \longrightarrow \mathrm{He}+\mathrm{X}^{+}+\mathrm{e}^{-} ; \text {Penning effect } \\
& \mathrm{X}^{+}+\mathrm{e}^{-} \longrightarrow \mathrm{X}^{*} \longrightarrow \mathrm{X}+\mathrm{hv}
\end{aligned}
$$

Ablated $\mathrm{X}$ atom from the material target collides via penning effect with the metastable $\mathrm{He}$ atoms accumulated in the $\mathrm{He}$ gas plasma region, resulting in $\mathrm{X}$ ion and free-electron (Eq. 1). Multiple collisions among free electrons, He metastable atoms, and other constituents in the plasma region reduce electron's energy and finally electron recombines with the $\mathrm{X}$ ion to produce $\mathrm{X}^{*}$, which results in the emission of $\mathrm{X}$ atom as displayed in Eq. 2. Figure 5(b) shows a zoomed area of Fig. 5(a) in the range of $390 \mathrm{~nm}$ to $400 \mathrm{~nm}$. It is seen that the emission intensities of ionic $\mathrm{Ca}$ at $393.3 \mathrm{~nm}$ and $396.8 \mathrm{~nm}$ only faintly occur with quite noise.

The present technique was then employed to identify and analyze elements in the blood serum obtained from tuberculosis (TB) patient. Figure- 6 is a spectrum taken from the human blood serum of TB patients and zoomed area of Fig.-6 in the wavelength region of $390 \mathrm{~nm}$ to $400 \mathrm{~nm}$ (Fig. 6b). Total emission intensities of major and minor elements including $\mathrm{C}, \mathrm{Na}, \mathrm{H}$, and $\mathrm{O}$ obtained from both blood serum of normal and TB patients are almost the same. However, it should be noticed that the intensity of $\mathrm{Ca}$ as a trace element in the human blood serum of TB patients is significantly different from the normal patient case. Namely, the ionic $\mathrm{Ca}$ emission intensity in TB patients is almost four times higher than the case of a normal patient. Therefore, the existence of $\mathrm{Ca}$ atom in human blood serum can be used to distinguish the serum from the TB patient to a normal patient. The human blood of TB patients contains $\mathrm{Ca}$ as a trace element. ${ }^{18}$ Further detailed study on analysis of human blood serum from the TB patients will be carried out in the near future.

The reproducibility of the analytical intensities obtained from the human blood serum was then examined. Figure-7 shows the laser shot dependence to the $\mathrm{S} / \mathrm{N}$ ratio of the analyte, including ionic $\mathrm{Ca} 393.3 \mathrm{~nm}$, 
RASĀYAN J. Chem.

Vol. 14 | No. 4 |2413-2419| October- December | 2021

neutral O $777.7 \mathrm{~nm}$, neutral H $656.3 \mathrm{~nm}$, and neutral C $247.8 \mathrm{~nm}$ obtained from the blood serum of TB patients. Intensities of $\mathrm{Ca}, \mathrm{O}, \mathrm{H}$, and $\mathrm{C}$ have good stability with the number of laser shots in a different position.

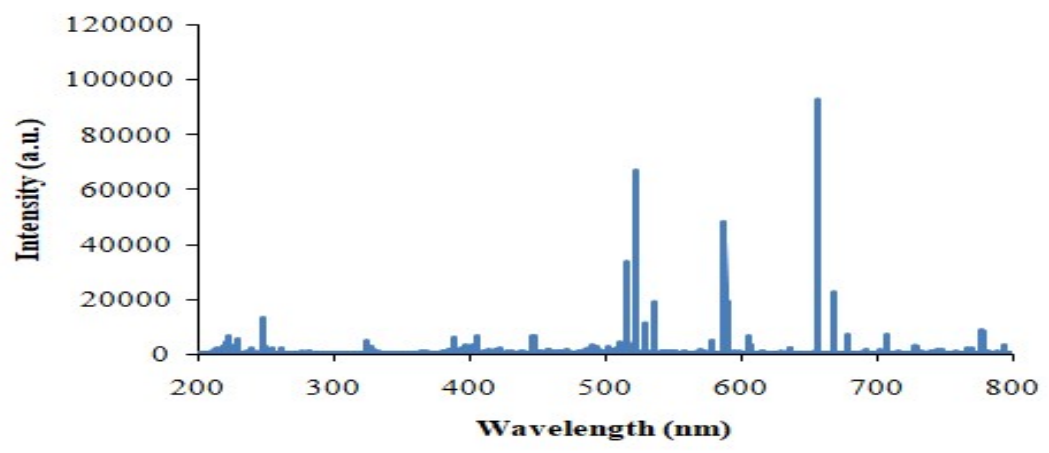

(a)

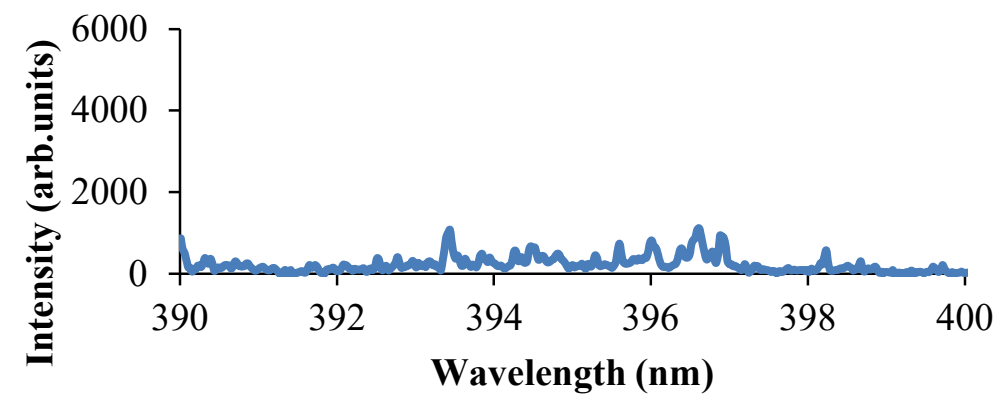

(b)

Fig.-5: The emission spectrum is taken from the human blood serum of a normal patient at a reduced pressure of He gas, (a) $200-800 \mathrm{~nm}$ and (b) $390-400 \mathrm{~nm}$

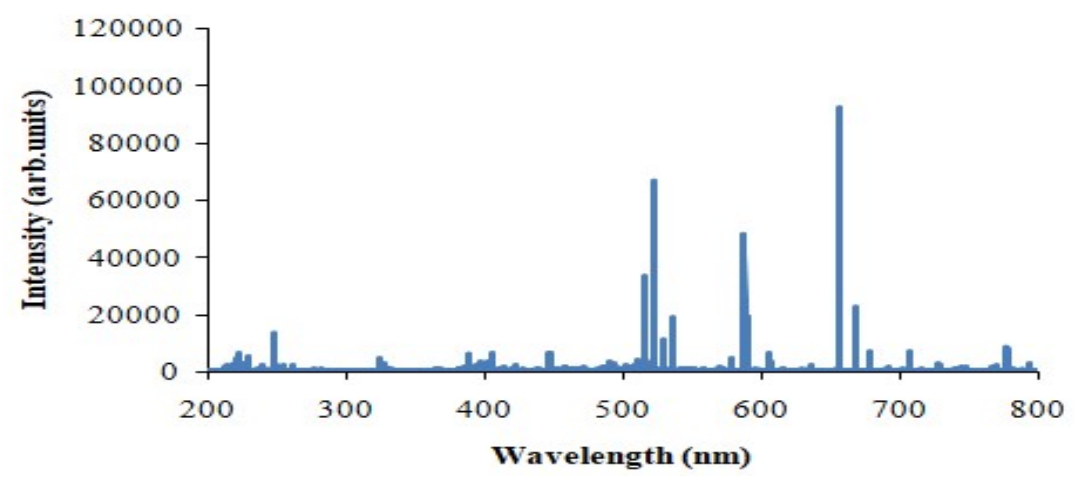

(a)

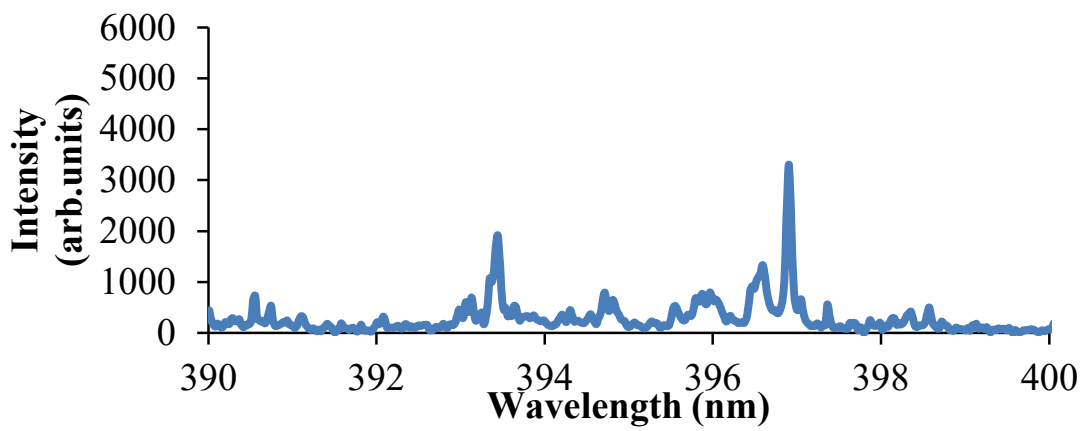

(b)

Fig.-6: Emission spectrum is taken from the human blood serum of TB patients at a reduced pressure of He gas, (a) 200-800 $\mathrm{nm}$ and (b) 390-400 nm 
RASĀYAN J. Chem.

Vol. 14 | No. 4 |2413-2419| October- December | 2021

The present technique has good precision in the analytical result and thus, it can be employed to the analysis of organic liquid material such as human blood serum, which is usually difficult to perform using the standard LIBS technique.

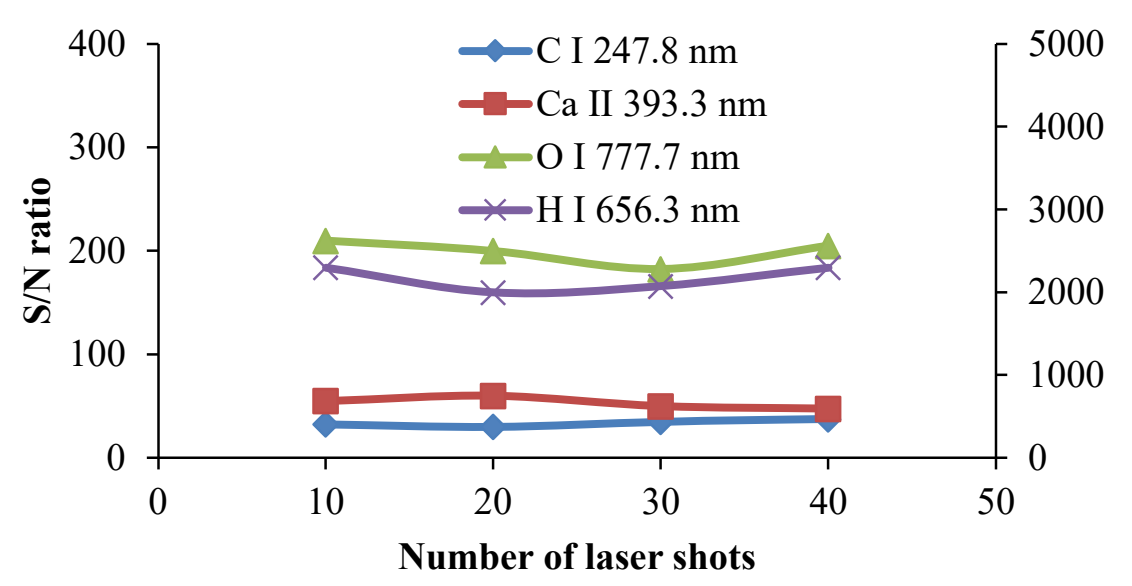

Fig.-7: Laser shot dependence of the emission intensities of analyte taken from the human blood serum of TB patient at a reduced pressure of $\mathrm{He}$ gas

\section{CONCLUSION}

Identification and analysis of human blood taken from the normal and TB patients have been realized by LIBS utilizing $355 \mathrm{~nm} \mathrm{Nd:YAG} \mathrm{laser} \mathrm{at} \mathrm{a} \mathrm{reduced} \mathrm{pressure} \mathrm{of} \mathrm{He} \mathrm{surrounding} \mathrm{gas.} \mathrm{Identification} \mathrm{of}$ elements including $\mathrm{C}, \mathrm{H}, \mathrm{O}$, and $\mathrm{Na}$ in human blood serum was successfully performed. The intensities of those elements are very stable with the number of laser shots in different positions. It was also found that based on trace elemental identification of $\mathrm{Ca}$, the human blood serum from the TB patient contains a higher concentration of $\mathrm{Ca}$ compared to the case of a normal patient. This present method has a high possibility to be applied to the analysis of TB patients based on human blood serum as an early diagnosis of TB disease.

\section{ACKNOWLEDGMENT}

This study was financially supported by the Ministry of Research and Technology/National Research and Innovation Agency under the Research Grant of PDUPT 225-90/UN7.6.1/PP/2021

\section{REFERENCES}

1. J. S. Tratnik, D. Mazej, M. Horvart, International Journal of Environmental Research and Public Health, 16, 2287(2019), https://doi.org/10.3390/ijerph16132287

2. R. Gaudiuso, N. Melikechi, Z. A. Abdel-salam, M. A. Harith, V. Palleschi, V. Motto-Ros, B. Busser, Spectrochimica Acta Part B: Atomic Spectroscopy, 152, 123(2019), https://doi.org/10.1016/j.sab.2018.11.006

3. P. Heitland, H. D. Köster, Journal of Trace Elements in Medicine and Biology, 64, 126706(2021), https://doi.org/10.1016/j.jtemb.2020.126706

4. J. M. Harrington, D. J. Young, A. S. Essader, S. J. Sumner, K. E. Levine, Biological Trace Element Research, 160, 132(2014). https://doi.org/10.1007/s12011-014-0033-5

5. D. Grote-Koska, R. Klauke, K. Brand, G. Schumann, Metrologia, 55, 245(2018). https://doi.org/10.1088/1681-7575/aaaa3f

6. S. C. Jantzi, V. Motto-Ros, F. Trichard, Y. Markushin, N. Melikechi, A. D. Giacomo, Spectrochimica Acta Part B: Atomic Spetroscopy, 115, 52(2016), https://doi.org/10.1016/j.sab.2015.11.002

7. S. Musazzi, U. Perini, Laser-induced Breakdown Spectroscopy: Theory and Applications, Springer Series in Optical Sciences: Berlin, 2014.

8. J. L. Gottfried, F. C. De Lucia Jr, Army Research Laboratory, 1, 2010.

9. D. W. Hahn, N. Omenetto, Applied Spectroscopy, 64, 335A(2010), https://journals.sagepub.com/doi/10.1366/000370210793561691 
RASĀYAN J. Chem.

Vol. 14 | No. 4 |2413-2419| October- December | 2021

10. D. W. Hahn, N. Omenetto, Applied Spectroscopy, 66, 347(2012), https://journals.sagepub.com/doi/10.1366/11-06574

11. A. Khumaeni, Z. S. Lie, H. Niki, K. Fukumoto, T. Maruyama, K. Kagawa, Optical Review, 17, 285(2010), https://doi.org/10.1007/s10043-010-0050-3

12. Z. S. Lie., M. O. Tjia, R. Hedwig, M. M. Suliyanti, S. N. AbdulMadjid, N. Idris, A. M. Marpaung, M. Pardede, E. Jobiliong, M. Ramli, H. Suyanto, K. Fukumoto, K. Kagawa, K. H. Kurniawan, Journal of Applied Physics, 113, 053301(2013), https://doi.org/10.1063/1.4789817

13. T. Silbertstein, M. Saphier, Y. Mashiach, O. Paz-Tal, O. Saphier, The Journal of maternal-Fetal and Neonatal Medicine, 28, 88(2015), https://doi.org/10.3109/14767058.2014.905907

14. R. Ahmed, J. Iqbal, M. A. Baig, Laser Physics Letters, 12, 066102(2015), https://doi.org/10.1088/1612-2011/12/6/066102

15. Z. S. Lie, A. Khumaeni, K. Kurihara, K. H. Kurniawan, Y. I. Lee, K. Fukumoto, K. Kagawa, H. Niki, Japanese Journal of Applied Physics, 50, 122701(2011), https://doi.org/10.1143/JJAP.50.122701

16. Z. Sukra Lie, A. Khumaeni, T. Maruyama, K. Fukumoto, H. Niki, K. Kagawa, Journal of Analytical Atomic Spectrometry, 26, 1451(2011), https://doi.org/10.1039/C0JA00193G

17. A. Khumaeni, Z. S. Lie, Y. I. Lie, K. Kurihara, K. H. Kurniawan, K. Fukumoto, K. Kagawa, H. Niki, Japanese Journal of Applied Physics, 51, 082403(2012), https://doi.org/10.1143/JJAP.51.082403

18. Z. Sepehri, D. Arefi, N. Mirzaei, A. Afshari, Z. Kiani, A. Sargazi, A. P. Mishkar, H. O. Oskoee, M. R. Masjedi, A. Sargazi, S. Ghavami, 2018, Journal of Trace Elements in Medicine and Biology, 50, 161, https://doi.org/10.1016/j.jtemb.2018.06.024

[RJC-5975/2020] 